\title{
Partial Characterization of Bacteriocins Produced by Lactobacillus reuteri 2-20B and Pediococcus acidilactici 0-11A Isolated from Fura, a Millet-Based Fermented Food in Ghana
}

\author{
James Owusu-Kwarteng $^{1,2}$, Kwaku Tano-Debrah ${ }^{2}$, Fortune Akabanda ${ }^{1,2}$, Dennis S. Nielsen ${ }^{3} \&$ Lene Jespersen $^{3}$ \\ ${ }^{1}$ Department of Applied Biology, Faculty of Applied Sciences, University for Development Studies, Navrongo, \\ Ghana \\ ${ }^{2}$ Department of Nutrition and Food Science, University of Ghana, Legon-Accra, Ghana \\ ${ }^{3}$ University of Copenhagen, Faculty of Life Sciences, Centre for Advanced Food Studies (LMC), Department of \\ Food Science, Rolighedsveij 30 DK 1958 Frederiksberg C, Denmark
}

Correspondence: James Owusu-Kwarteng, Department of Applied Biology, Faculty of Applied Sciences, University for Development Studies, P. O. Box 24, Navrongo, Ghana. Tel: 233-209-265-738. E-mail: jowusukwarteng@yahoo.co.uk

Received: October 8, 2012 Accepted: December 11, 2012 Online Published: January 15, 2013

doi:10.5539/jfr.v2n1p50 URL: http://dx.doi.org/10.5539/jfr.v2n1p50

\begin{abstract}
Cell-free supernatants (CFS) produced by 369 LAB strains previously isolated from fura and identified based on sequencing of their 16S rRNA genes were screened for their antagonistic activities against pathogenic bacteria including Bacillus cereus PA24, Escherichia coli SKN 541, Enterococcus faecalis 103907 CIP, Staphylococcus aureus ATCC 19095 and Listeria monocytogenes Scott A, using the agar well diffusion method. Bacteriocins of Lactobacillus reuteri 2-20B and Pediococcus acidilactici 0-11A were further evaluated for their stability when subjected to a range of $\mathrm{pH}$ conditions, enzymatic and heat treatments. Growth and bacteriocin production rates as well as influence of media composition on bacteriocin production were also evaluated. Cell free supernatants of $L b$. reuteri and $P d$. acidilactici strains exhibited the widest inhibitory activities whereas CFS of $L b$. fermentum exhibited the least inhibitory activity towards the tested pathogens. Bacteriocins of Lb. reuteri 2-20B and $P d$. acidilactici $0-11 \mathrm{~A}$ retained their antibacterial activities over a wide range of $\mathrm{pH}$. Whereas the antimicrobial activity of $L b$. reuteri 2-20B was lost after being subjected to temperature of $90^{\circ} \mathrm{C}$ for $1 \mathrm{~h}, \mathrm{CFS}$ of $P d$. acidilactici 0-11A remained stable after autoclaving at $121^{\circ} \mathrm{C}$ for $15 \mathrm{~min}$. Again, the antimicrobial activities of both $L$ b. reuteri 2-20B and $P d$. acidilactici $0-11 \mathrm{~A}$ were lost when the CFSs were subjected to the action of proteolytic enzymes but remained active under the actions of catalase, lipase and $\alpha$-amylase. Production of bacteriocins by both $L b$. reuteri $2-20 \mathrm{~B}$ and $P d$. acidilactici $0-11 \mathrm{~A}$ were growth associated and influeced by media composition.
\end{abstract}

Keywords: bacteriocin, cell free supernatant, lactic acid bacteria, fura, traditional fermentation

\section{Introduction}

Millet (Pennisetum glaucum) is a cereal for the production of many common staple foods in West Africa. In Ghana, millet is used for the production of fermented foods such as koko and koko sour water, furo-furo, maasa, and fura. Fura a millet-based spontaneously fermented dumpling is produced in parts of West Africa including Ghana. The microorganisms associated with fura processing have been isolated and identified by both classical and molecular biology-based techniques to include lactic acid bacteria and yeasts (Owusu-Kwarteng et al., 2012).

Lactic acid bacteria (LAB) have a long history of application in fermented foods because of their beneficial influence on nutritional, organoleptic, and safety and preservative characteristics (Hammes \& Vogel, 1995; Leroy \& De Vuyst, 2004). During fermentation, LAB displays a range of antimicrobial activities due to the production of organic acids and bioactive molecules such as ethanol, formic acid, fatty acids, hydrogen peroxide $\left(\mathrm{H}_{2} \mathrm{O}_{2}\right)$, and diacetyl. The screening of LAB for antimicrobial activity has shown that, besides acidification, some LAB produce inhibitory substances other than organic acids. Thus, certain strains of LAB produce bacteriocins and bacteriocin-like molecules that display antimicrobial activities (De Vuyst \& Vandamme, 1994) which 
inhibits the growth of pathogenic and food spoilage microorganisms thereby ensuring safety of the product.

Whereas the involvement of LAB in fura and similar other traditional fermented foods is based on spontaneous fermentations, a deliberate addition of the isolated microorganisms as starters to the food matrix would result in a high degree of control over the fermentation process to yield a more standardized end product. Owusu-Kwarteng et al. (2012) identified the LAB isolated during traditional fura processing in Ghana. However, no study has so far screened the isolated LAB isolated from fura for their ability to produce bacteriocins. The objective of this study was therefore to screen LAB isolated during traditional fura processing for their ability to produce bacteriocins against selected pathogens, and to assess their effectiveness when subjected to some food processing environments. This is geared towards the provision of rational basis for further research in selecting potential LAB strains for use as starter cultures, co-cultures, or bio-protective cultures, to improve the quality and safety of fura and other fermented food products.

\section{Materials and Methods}

\subsection{Lactic Acid Bacteria}

Lactic acid bacteria used in this study were previously isolated during traditional fura processing in Ghana. They were identified by a combination of phenotypic and genotypic methods including conventional morphological characteristics and carbohydrate fermentation profiling, $(\mathrm{GTG})_{5}$ - based rep-PCR fingerprinting and 16S rRNA gene sequencing as described elsewhere (Owusu-Kwarteng et al., 2012).

\subsection{Indicator Strains (Pathogens)}

Indicator organisms used in this study and their sources are shown in Table 1.

Table 1. Indicator organisms and their sources/origin

\begin{tabular}{ll}
\hline Indicator organisms & Source \\
\hline Bacillus cereus PA24 & Food condiment, Copenhagen University culture collection \\
Escherichia coli $81 \mathrm{nr}$.1495 SKN 541 & Copenhagen University culture collection \\
Enterococcus faecalis 103907 CIP & Obtained from Food Research Institute, Ghana \\
Staphylococcus aureus ATCC 19095 & Clinical, American type culture collection \\
Listeria monocytogenes Scott A, SKN 1014 & Copenhagen University culture collection \\
\hline
\end{tabular}

\subsection{Preparation of Cell-free Supernatant (CFS)}

Each LAB isolate was grown in MRS broth at $30^{\circ} \mathrm{C}$ for $48 \mathrm{~h}$ in a shaking incubator. The culture extracts were obtained by centrifugation at 5,000 g for $10 \mathrm{~min}$. the supernatants were decanted and the pHs adjusted to 6.5 with $\mathrm{NaOH}\left(1 \mathrm{~mol} \mathrm{~L}^{-1}\right)$, to eliminate the effect of acidity (Mathieu et al., 1993). Inhibitory activity of hydrogen peroxide was eliminated by the addition of catalase ( $5 \mathrm{mg} \mathrm{ml}^{-1}$, Sigma, C-100 bovine liver) (Daba et al., 1993) and filtered through $0.20 \mu \mathrm{m}$ pore size syringe filters (Sartorius, Minisart ${ }^{\circledR}$, Göttingen, Germany).

\subsection{Screening of LAB for Antagonistic Activity against Pathogenic Bacteria}

The agar-well diffusion method was employed in the screening LAB for bacteriocin activities. Indicator lawns were prepared by mixing (inoculating) $20 \mathrm{ml}$ of BHI molten agar media with $100 \mu 1$ (approximately $10^{7} \mathrm{cfu} / \mathrm{ml}$ ) of an overnight culture of each indicator organism and allowing to solidify in a Petri dish. Wells were cut into the agar with a sterile $6 \mathrm{~mm}$ diameter cork borer and sealed with two drops of sterile agar. Fifty microlitres $(50 \mu \mathrm{l})$ of the filtered cell-free supernatant of test strains were separately placed into the wells. The plates, prepared in duplicate, were kept at $4^{\circ} \mathrm{C}$ for $24 \mathrm{~h}$ (Bonade et al., 2001) to allow pre-diffusion of the CFS into the agar and then incubated at $37^{\circ} \mathrm{C}$ for $24 \mathrm{~h}$. They were then observed for possible clearing of zones (inhibition zones). The antimicrobial activity was determined by measuring the diameter of the inhibition zones around the well. Results were recorded as no inhibition (-), weak inhibition (+), moderate inhibition (++) and strong inhibition (+++) when the diameter is $<1 \mathrm{~mm}, 1-5 \mathrm{~mm}, 6-10 \mathrm{~mm}$ and $>10 \mathrm{~mm}$ respectively.

\subsection{Sensitivity of CFS to $\mathrm{pH}$ Changes, Enzyme and Heat Treatment}

Sensitivity studies were conducted with CFSs obtained from $L$ b. reuteri $2-20 \mathrm{~B}$ and $P d$. acidilactici $0-11 \mathrm{~A}$. The effect of $\mathrm{pH}$ on the bacteriocins was determined by adjusting the cell-free supernatant to $\mathrm{pH} 2.0$ to 9.0 (at increments of one $\mathrm{pH}$ unit) with sterile $1 \mathrm{~N} \mathrm{HCl}$ or $1 \mathrm{~N} \mathrm{NaOH}$. After $2 \mathrm{~h}$ of incubation at room temperature, the 
samples were readjusted to $\mathrm{pH} 6.5$ with sterile $1 \mathrm{~N} \mathrm{HCl}$ or $1 \mathrm{~N} \mathrm{NaOH}$ and the activity determined by the agar well diffusion method. For enzyme treatment, $2 \mathrm{ml}$ of CFS were incubated for $1 \mathrm{~h}$ in the presence of $1.0 \mathrm{mg} \mathrm{ml}^{-1}$ (final concentration) trypsin, pronase $\mathrm{E}$, proteinase $\mathrm{K}$, lipase and $\alpha$-amylase and then tested for antimicrobial activity. For heat treatment, the CFS were heated in water bath at $30^{\circ} \mathrm{C}$ to $100^{\circ} \mathrm{C}$ (at increments of $10^{\circ} \mathrm{C}$ ) for $1 \mathrm{~h}$, or autoclaved $\left(121^{\circ} \mathrm{C}\right)$ for $15 \mathrm{~min}$ and tested for their bacteriocin activities using the agar well diffusion method described in section 2.4 .

\subsection{Growth Characteristics and Bacteriocin Production}

Growth experiments were carried out in $500 \mathrm{ml}$ ErlenMeyer flask containing $250 \mathrm{ml}$ MRS broth. An overnight pre-culture of $L b$. reuteri $2-20 \mathrm{~B}$ and $P d$. acidilactici $0-11 \mathrm{~A}$ were used for the inoculations of MRS broths at initial densities of $c a 10^{3} \mathrm{cfu} / \mathrm{ml}$. At $2 \mathrm{~h}$ intervals, samples were removed from the culture and used for viable plate count (cfu/ml), OD (600nm), $\mathrm{pH}$ measurements, and antimicrobial activity. The antimicrobial concentration of each sample was estimated using the critical method of dilution. Arbitrary Unit $\mathrm{ml}^{-1}$ (AU/ml) was calculated as the inverse of the highest two-fold dilution which induced definite inhibition.

\subsection{Effect of Medium Composition on Bacteriocin Production}

The effect of medium composition on bacteriocin production was performed according to Todorov and Dicks (2007) with slight modification. Briefly, Lb. reuteri $2-20 \mathrm{~B}$ and $P$ d. acidilactici $0-11$ A were separately grown in $10 \mathrm{ml}$ MRS broth for $20 \mathrm{~h}$ at $30^{\circ} \mathrm{C}$. The cells were harvested by centrifugation $\left(8000 \mathrm{xg}, 10 \mathrm{~min}, 4^{\circ} \mathrm{C}\right)$, and the pellet re-suspended in $10 \mathrm{ml}$ sterile peptone water. Four $\mathrm{ml}$ of the cell suspension was used to inoculate $200 \mathrm{ml}$ of the following media: (a) MRS broth (de Man et al., 1960) without organic nutrients supplemented with tryptone $(20.0 \mathrm{~g} / \mathrm{L})$, meat extract $(20.0 \mathrm{~g} / \mathrm{L})$, yeast extract $(20.0 \mathrm{~g} / \mathrm{L})$, tryptone $(12.5 \mathrm{~g} / \mathrm{L})$ plus meat extract $(7.5$ $\mathrm{g} / \mathrm{L})$, tryptone $(12.5 \mathrm{~g} / \mathrm{L})$ plus yeast extract $(7.5 \mathrm{~g} / \mathrm{L})$, meat extract $(10.0 \mathrm{~g} / \mathrm{L})$ plus yeast extract $(10.0 \mathrm{~g} / \mathrm{L})$, or a combination of tryptone $(10.0 \mathrm{~g} / \mathrm{L})$, meat extract $(5.0 \mathrm{~g} / \mathrm{L})$ and yeast extract $(5.0 \mathrm{~g} / \mathrm{L})$, respectively; (b) MRS broth, i.e. with $20.0 \mathrm{~g} / 1 \mathrm{D}$-glucose; (c) MRS broth without D-glucose, supplemented with $20.0 \mathrm{~g} / \mathrm{L}$ fructose, sucrose, lactose, mannose, and maltose, respectively; (d) MRS broth supplemented with $0.0,0.1,0.2$, and 0.5 $\mathrm{ml} / \mathrm{L}$ tween 80 respectively; (e) MRS broth supplemented with $0.0,1.0,2.0$ and $4.0 \mathrm{~g} / \mathrm{L}$ glycerol respectively. All cultures were incubated at $30^{\circ} \mathrm{C}$ (initial $\mathrm{pH}$ of 6.5).

\subsection{Statistical Analysis}

Data obtained were subjected to one-way analysis of variance (ANOVA) and means were separated by Tukey's family error rate multiple comparison test $(\mathrm{p}<0.05)$ using the MINITAB statistical software package (MINITAB Inc. Release 14 for windows, 2004).

\section{Results and Discussion}

\subsection{Screening of LAB for Antimicrobial Activities}

A total of 369 previously identified strains of LAB (Owusu-Kwarteng et al., 2012) were first screened for their antimicrobial activities. These comprised 176 strains of $L b$. fermentum, 82 strains of $W$. confusa, 60 strains of $L b$. reuteri and 51 strains of $P d$. acidilactici (Table 2). Antagonistic activities of CFSs of the LAB is shown in Table 2. The result demonstrated a diversity of the strains, within and between species, in their ability and the extent to which they inhibit the growth of different pathogenic bacteria. Strains of $L b$. reuteri and $P d$. acidilactici displayed the widest inhibitory activities against the indicator pathogens whereas $L b$. fermentum species showed the least inhibitory activity spectrum against the pathogens. Staphylococcus aureus enterotoxin A producer was the most susceptible pathogen with about $57 \%$ and $52 \%$ strains of $L b$. reuteri and $P d$. acidilactici respectively showing inhibition towards S. aureus ATCC 19095. Generally, the Gram-positive pathogenic bacteria were more susceptible to the inhibitory actions of the isolated LAB than the Gram-negative indicator organisms.

Several bacteriocin producing LAB have been isolated from various traditional spontaneous fermented foods such as bosa (Todorov \& Dicks, 2006), kenkey (Olsen et al., 1995), and ogi and fufu (Sanni et al., 1999; Olukoya et al., 1993). Similarly, strains of $L b$. reuteri and $P d$. acidilactici in this study produced bacteriocins which showed inhibition against both the Gram-positive and Gram-negative bacteria (E. coli SKN541) although the Gram-positive bacteria were generally more susceptible. Bacteriocins of LAB have been defined as bioactive peptides or proteins that are active against Gram-positive bacteria and usually against species closely related to the producer strain (De Vuyst \& Vandamme, 1994). There are however, reports on bacteriocins of LAB with activity against a broad spectrum of Gram-positive and Gram-negative bacteria, including Klebsiella pneumoniae, E. coli, and Pseudomonas spp. (Todorov \& Dicks 2005) which are not necessarily closely related to the producer strains. 


\subsection{Effect of Heat, Enzymes and pH Treatments on Activity of Bacteriocins}

The effect of different treatments on inhibitory activity of bacterioncins of Lb. reuteri 2-20B and Pd. acidilactici 0-11A against $S$. aureus ATCC 19095 is shown in Table 3. Inhibitory activity of these bacteriocins reduced significantly $(\mathrm{p}<0.05)$ with increasing temperature and was completely inactivated at temperatures above $90^{\circ} \mathrm{C}$. The antibacterial activity was lost when the bacteriocins were subjected to the action of proteolytic enzymes such as pronase $\mathrm{E}$, proteinase $\mathrm{K}$, and trypsin but remained active under the action of catalase, lipase and $\alpha$-amylase. Both bacteriocins remained active after being subjected to a wide range of $\mathrm{pH}$ conditions. The bacteriocin produced by $L b$. reuteri $2-20 \mathrm{~B}$ remained active over a wide range of temperatures up to $80^{\circ} \mathrm{C}$ for $1 \mathrm{~h}$. On the other hand, bacteriocin of $P d$. acidilactici 0-11A was stable up to $121^{\circ} \mathrm{C}$ (autoclaving) for $1 \mathrm{~h}$ although there was a significant $(\mathrm{p}<0.05)$ decrease in activity after autoclaving. It thus suggested that bacteriocin of $L b$. reuteri $2-20 \mathrm{~B}$ may not be suitable in foods before they are cooked at temperatures above $80^{\circ} \mathrm{C}$ and can be considered for usage after cooking if such high temperatures are required. Some other bacteriocins of LAB, especially those of sourdough origins, have displayed temperature stabilities between 90 and $121^{\circ} \mathrm{C}$ (Van Der Merwe et al., 2004; Mollendorff et al., 2006; Mezaini et al., 2009). On the contrary, the activity of bavaricin MN, another bacteriocin produced by a $\mathrm{Lb}$. bavaricus strain isolated from meat, is completely lost after heating at $60^{\circ} \mathrm{C}$ for $15 \mathrm{~min}$ and at $100^{\circ} \mathrm{C}$ for $10 \mathrm{~min}$ (Lewus \& Montville, 1992). Bacteriocins of both Lb. reuteri 2-20B and $P d$. acidilactici 0 -11 A remained active over a wide range of $\mathrm{pH}$ conditions although there was reduced activity at more alkaline $\mathrm{pH}$. A similar report has shown that at $\mathrm{pH} 9.0$ and above, there was a significant loss in activity of plantaricin ST31 (Todorov et al., 1999). Notwithstanding, these bacteriocins will remain stable at $\mathrm{pH}$ conditions prevailing in most food environments. Constant changes in $\mathrm{pH}$ and medium composition during fermentation however led to changes in activity levels of bacteriocins produced by Lb. mesenteroides L124, and Lb. curvatus L442 (Mataragas et al., 2003). The inactivation of both bacteriocins of Lb. reuteri 2-20B and Pd. acidilactici $0-11 \mathrm{~A}$ by proteolytic enzymes while remaining active under the influence of catalase, lipase and $\alpha$-amylase was further confirmation of the peptidic or proteinaceous nature of bacteriocins and that the zones of inhibition observed were not due to the action of hydrogen peroxides. Similar observations have been made for other bacteriocins (Todorov \& Dicks 2004; Mezaini et al., 2009). Trypsin and pronase E completely inhibited the activity of bavaricin A (Larsen et al., 1993) and plantaricin ST31 (Todorov et al., 1999).

Table 2. Antagonistic activities of predominant lactic acid bacteria isolated from fura

\begin{tabular}{llllll}
\hline & \multicolumn{5}{c}{ Indicator organisms } \\
\cline { 2 - 5 } LAB & S. aureus & B. cereus PA24 & E. coli SKN 54 & $\begin{array}{l}\text { Ent. Faecalis } \\
103907 \text { CIP }\end{array}$ & $\begin{array}{l}\text { L. monocytogenes } \\
\text { scott A }\end{array}$ \\
\hline Lb. fermentum & $-(82) \mathrm{a}$ & $-(100)$ & $-(98)$ & $-(87)$ & $-(91)$ \\
$\mathrm{n}=176$ & $+(18)$ & $+(0)$ & $+(2)$ & $+(13)$ & $+(9)$ \\
& $++(0)$ & $++(0)$ & $++(0)$ & $++(0)$ & $++(0)$ \\
& $+++(0)$ & $+++(0)$ & $+++(0)$ & $+++(0)$ & $+++(0)$ \\
Lb. reuteri & $-(43)$ & $-(70)$ & $-(73)$ & $-(61)$ & $-(53)$ \\
$\mathrm{n}=60$ & $+(28)$ & $+(30)$ & $+(27)$ & $+(26)$ & $+(36)$ \\
& $++(10)$ & $++(0)$ & $++(0)$ & $++(8)$ & $++(6)$ \\
& $+++(8)$ & $+++(0)$ & $+++(0)$ & $+++(5)$ & $+++(5)$ \\
W. confusa & $-(71)$ & $-(91)$ & $-(95)$ & $-(74)$ & $-(82)$ \\
$\mathrm{n}=82$ & $+(29)$ & $+(9)$ & $+(5)$ & $+(21)$ & $+(18)$ \\
& $++(0)$ & $++(0)$ & $++(0)$ & $++(5)$ & $++(0)$ \\
& $+++(0)$ & $+++(0)$ & $+++(0)$ & $+++(0)$ & $+++(0)$ \\
Pd. acidilactici & $-(48)$ & $-(62)$ & $-(74)$ & $-(53)$ & $-(79)$ \\
$\mathrm{n}=51$ & $+(31)$ & $+(35)$ & $+(22)$ & $+(32)$ & $+(13)$ \\
& $++(9)$ & $++(3)$ & $++(4)$ & $++(7)$ & $++(0)$ \\
& $+++(12)$ & $+++(0)$ & $+++(0)$ & $+++(8)$ & $+++(8)$ \\
\hline
\end{tabular}

Values in parenthesis are percentages of the particular species (n) which showed inhibitions at the levels indicated before them; n: number of strains screened for inhibition; S: Staphylococcus, B: Bacillus, E: Escherichia, Ent: Enterococcus, L: Listeria, Lb. : Lactobacillus, W: Weissella Pd.: Pediococcus, - : no inhibition, + : weak inhibition, ++ : moderate inhibition, and +++ : strong inhibition. 


\subsection{Growth and Bacteriocin Production by Lb. reuteri 2-20B and Pd. acidilactici 0-11A}

Growth kinetics and bacteriocin production by $L$ b. reuteri 2-20B and $P d$. acidilactici $0-11 \mathrm{~A}$ were studied in MRS broth at $30^{\circ} \mathrm{C}$ with initial $\mathrm{pH}$ 6.5. Bacteriocin activities were first detected at the exponential growth phase for both $P d$. acidilactici $0-11 \mathrm{~A}$ and $L b$. reuteri 2-20B. Bacteriocin production increased with increasing cell concentration, reaching a maximum of $12800 \mathrm{AU} / \mathrm{ml}$ after $12 \mathrm{~h}$ and $14 \mathrm{~h}$ of growth for $P d$. acidilactici $0-11 \mathrm{~A}$ and Lb. reuteri $2-20 \mathrm{~B}$, respectively (Figure 1 ). The highest activities were recorded at the stationary growth phases. Bacteriocins of both $P d$. acidilactici $0-11 \mathrm{~A}$ and $L b$. reuteri $2-20 \mathrm{~B}$ remained active during the stationery growth phase but a reduction of acitivity was observed after $20 \mathrm{~h}$ and $22 \mathrm{~h}$ for Pd. acidilactici $0-11 \mathrm{~A}$ and $L b$. reuteri 2-20B respectively. Other studies have similarly found production of plantaricin ST31 in detectable amounts during the exponential growth phase, while maximum activities $(3200 \mathrm{AU} / \mathrm{ml})$ were observed in the stationary phase (Todorov et al., 1999). Again, BLIS C57 activity was detected after $6 \mathrm{~h}$ of incubation with a drastic increase at the stationary growth phase. A loss of activity was, however observed after $72 \mathrm{~h}$ of growth (Corsetti et al., 1996). A loss of bacteriocins activity after extended period of incubation has been attributed to factors such as proteolytic degradation, protein aggregation, adsorption to cell surfaces, and feedback regulation (Parente \& Ricciardi, 1994; Aasen et al., 2000).

Table 3. Effect of different treatments on inhibitory activity of cell-free supernatant of $L b$. reuteri 2-10B and $P d$. acidilactici 0-11A against Staphylococcus aureus enterotoxin A producer

\begin{tabular}{|c|c|c|c|c|}
\hline \multirow{2}{*}{ Heat } & \multicolumn{2}{|c|}{ Lb. reuteri 2-20B } & \multicolumn{2}{|c|}{ Pd. acidilactici 0-11A } \\
\hline & & & & \\
\hline treatment $\left({ }^{\circ} \mathrm{C}\right)$ & $1 \mathrm{I} \mathrm{Z} \mathrm{(mm)}$ & Relative activity & $1 I Z(\mathbf{m m})$ & Relative activity \\
\hline 30 & $12.3 \pm 1.5 \mathrm{a}$ & +++ & $13.2 \pm 1.0 \mathrm{a}$ & +++ \\
\hline 40 & $13.0 \pm 2.0 \mathrm{a}$ & +++ & $11.7 \pm 0.3 \mathrm{ab}$ & +++ \\
\hline 50 & $9.6 \pm 1.0 \mathrm{~b}$ & ++ & $11.3 \pm 0.8 \mathrm{ab}$ & +++ \\
\hline 60 & $7.7 \pm 0.6 \mathrm{c}$ & ++ & $9.7 \pm 0.6 \mathrm{~b}$ & ++ \\
\hline 70 & $4.7 \pm 1.2 \mathrm{~d}$ & + & $9.0 \pm 0.5 b$ & ++ \\
\hline 80 & $4.3 \pm 0.8 \mathrm{~d}$ & + & $7.6 \pm 0.6 c$ & ++ \\
\hline 90 & $0.0 \pm 0.0 \mathrm{e}$ & - & $8.0 \pm 1.0 \mathrm{c}$ & ++ \\
\hline 100 & $0.0 \pm 0.0 \mathrm{e}$ & - & $5.0 \pm 1.0 \mathrm{~d}$ & + \\
\hline 121(Autoclaving) & $0.0 \pm 0.0 \mathrm{e}$ & - & $5.7 \pm 0.6 \mathrm{~d}$ & + \\
\hline Control & $13.6 \pm 1.2 \mathrm{a}$ & +++ & $12.7 \pm 0.3 \mathrm{a}$ & +++ \\
\hline \multicolumn{5}{|c|}{ Enzymatic treatment } \\
\hline Catalaze & $13.0 \pm 1.0 \mathrm{e}$ & +++ & $12.4 \pm 0.8 \mathrm{e}$ & +++ \\
\hline Lipase & $12.7 \pm 1.2 \mathrm{e}$ & +++ & $13.2 \pm 1.1 \mathrm{e}$ & +++ \\
\hline Pronase E & $0.0 \pm 0.0 \mathrm{f}$ & - & $0.0 \pm 0.0 \mathrm{f}$ & - \\
\hline Proteinase K & $0.0 \pm 0.0 \mathrm{f}$ & - & $0.0 \pm 0.0 \mathrm{f}$ & - \\
\hline Trypsin & $0.0 \pm 0.0 \mathrm{f}$ & - & $0.0 \pm 0.0 \mathrm{f}$ & - \\
\hline$\alpha$-amylase & $12.3 \pm 2.1 \mathrm{e}$ & +++ & $13.3 \pm 1.4 \mathrm{e}$ & +++ \\
\hline Control & $13.8 \pm 1.2 \mathrm{e}$ & +++ & $13.7 \pm 0.5 \mathrm{e}$ & +++ \\
\hline \multicolumn{5}{|l|}{ pH treatment } \\
\hline 3 & $14.8 \pm 1.7 \mathrm{~h}$ & +++ & $15.5 \pm 1.3 \mathrm{~h}$ & +++ \\
\hline 4 & $15.3 \pm 2.1 \mathrm{~h}$ & +++ & $15.1 \pm 0.8 \mathrm{~h}$ & +++ \\
\hline 5 & $12.1 \pm 1.2 \mathrm{k}$ & +++ & $15.3 \pm 1.1 \mathrm{~h}$ & +++ \\
\hline 6 & $12.6 \pm 0.8 \mathrm{k}$ & +++ & $12.8 \pm 1.3 \mathrm{k}$ & +++ \\
\hline 7 & $11.5 \pm 1.5 \mathrm{k}$ & +++ & $13.2 \pm 0.7 \mathrm{k}$ & +++ \\
\hline 8 & $12.0 \pm 2.0 \mathrm{k}$ & +++ & $12.3 \pm 1.2 \mathrm{k}$ & +++ \\
\hline 9 & $8.7 \pm 2.1 \mathrm{j}$ & ++ & $4.7 \pm 0.8 \mathrm{~g}$ & + \\
\hline
\end{tabular}

${ }^{1}$ Values are means of three replicate experiments; \pm : standard deviations (SD). Means with different letters as superscripts for each treatment column are significantly different $(\mathrm{p}<0.05)$. -: no inhibition, + : weak inhibition, ++ : moderate inhibition, +++: strong inhibition, IZ: Inhibition zone. 
Pd. acidilactici $0-11 \mathrm{~A}$

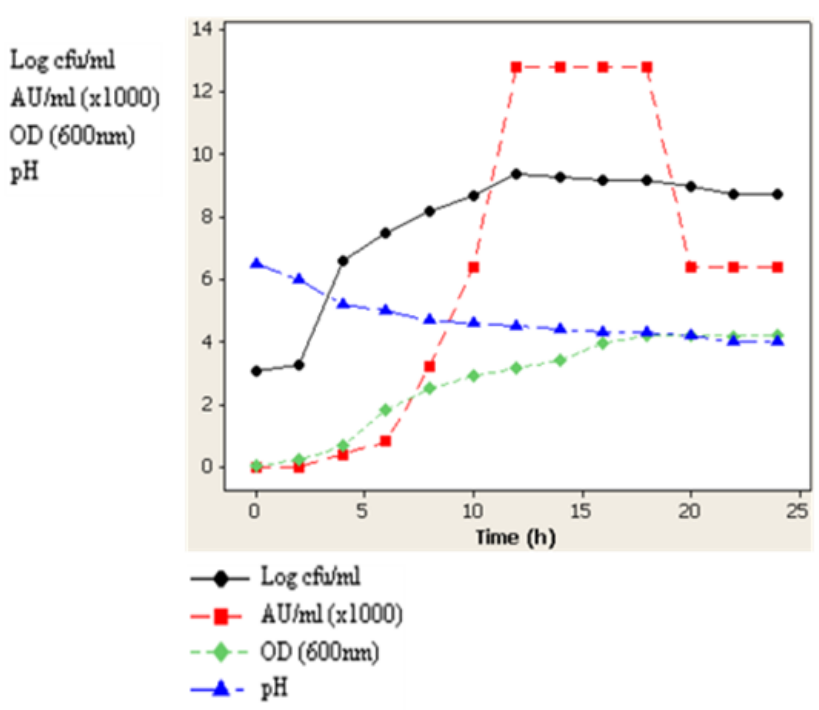

Lb. reuteri $2-20 \mathrm{~B}$

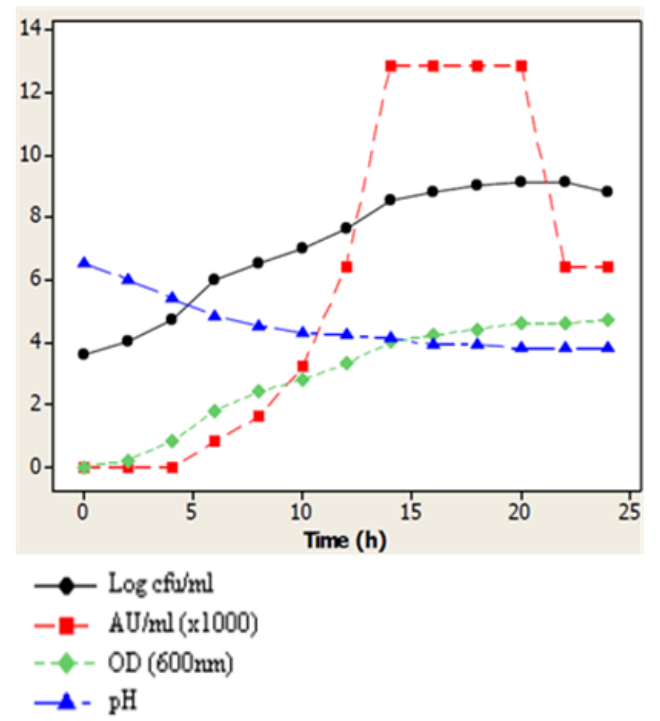

Figure 1. Growth kinetics and bacteriocin production by $P d$. acidilactici $0-11 \mathrm{~A}$ and $L b$. reuteri $2-20 \mathrm{~B}$. Growth experiments were conducted at initial $\mathrm{pH}$ of 6.5 at $30^{\circ} \mathrm{C}$

\subsection{Influence of Media Composition on Bacteriocin Production by Pd. acidilactici 0-11A and Lb. reuteri 2-20B}

Growth in basal medium containing tryptone as sole nitrogen source yielded bacteriocin activities of 6400 $\mathrm{AU} / \mathrm{ml}$ and $12800 \mathrm{AU} / \mathrm{ml}$ for $P d$. acidilactici $0-11 \mathrm{~A}$ and Lb. reuteri 2-20B respectfully. For $P d$. acidilactici, the use of yeast extract, meat extract, or a combination of both reduced bacteriocin acitivies levels to 800,3200 and $3200 \mathrm{AU} / \mathrm{ml}$ respectively. Similarly, for $\mathrm{Lb}$. reuteri $2-20 \mathrm{~B}$, the use of yeast extract, meat extract, or a combination of both resuted in reduced bacteriocin acitivies levels to 1600,6400 and $3200 \mathrm{AU} / \mathrm{ml}$ respectively (Table 4). Tryptone therefore seemed to be the major driver for optimal bacteriocin production by both $P d$. acidilactici $0-11 \mathrm{~A}$ and $L$ b. reuteri $2-20 \mathrm{~B}$ as tryptone alone or in combination with other nitrogen sources yielded the highest bacteriocin acitivity $(12800 \mathrm{AU} / \mathrm{ml})$. Different bacteriocin producing LAB may require specific nitrogen cources for optimal activities. Like reported in this paper, tryptone has been a key nitrogen source required for optimal production of bacteriocins ST151BR (Todorov \& Dicks, 2004), ST712BZ (Todorov \& Dicks, 2007), and plantaracin 432 (Verellen et al., 1998). Different bacteriocin activity levels were observed for both $P d$. acidilactici $0-11 \mathrm{~A}$ and $L b$. reuteri $2-20 \mathrm{~B}$ when different carbohydrates were used as the sole carbon sources (Table 4). Glucose as a carbon source stimulated the highest bacteriocin production $(12800 \mathrm{AU} / \mathrm{ml})$ for both bacteria. Whereas mannose stimulated the production of bacteriocin by Pd. acidilactici $0-11 \mathrm{~A}$, bacteriocin production by $L b$. reuteri $2-20 \mathrm{~B}$ was reduced to $800 \mathrm{AU} / \mathrm{ml}$. Owing to its molecular size, rapid uptake, utilization and cellular energy conversion, glucose has been considered as the usual carbon source for bacterial growth media. However, some bacteria possess abilities owing to their enzymatic activities, to utilize other sugars as carbon sources for growth and for the production of bacteriocins, although bacteriocin activities may vary depending on the carbon source (Todorov \& Dicks, 2006). There was a general increase in bacteriocin activities by $P d$. acidilactici $0-11 \mathrm{~A}$ and $L b$. reuteri 2-20B with increasing addition of tween 80 (Table 4). In a tween 80 free medium, bacteriocin activity levels of 400 and $800 \mathrm{AU} / \mathrm{ml}$ were observed for $P d$. acidilactici $0-11 \mathrm{~A}$ and $L b$. reuteri 2-20B respectively. However, the addition of 0.1 and $0.2 \mathrm{ml}$ of tween 80 per liter of medium achieved the highest bacteriocin activity $(12800 \mathrm{AU} / \mathrm{ml})$ for $P d$. acidilactici $0-11 \mathrm{~A}$ and $L b$. reuteri 2-20B respectively. The influence of tween 80 on bacteriocins activity has been attributed to changes in charges on the cell wall surface of producer strains, thereby preventing adsorption of bacteriocins onto the cells (Mørtvedt-Abilgaard et al., 1995). A reduction in bacteriocin activities were observed with the addition of glycerol (Table 4), an observation which may be due to osmotic stress or reduced water activity. Maximum bacteriocin activities were recorded in the absence of glycerol for both $P d$. acidilactici $0-11 \mathrm{~A}$ and $L b$. reuteri 2-20B. 
Table 4. Effect of medium composition on bacteriocin activities of $P d$. acidilactici $0-11 \mathrm{~A}$ and $L b$. reuteri 2-20B

\begin{tabular}{|c|c|c|c|}
\hline & & Pd. acidilactici 0-11A & Lb. reuteri $2-20 \mathrm{~B}$ \\
\hline Media composition(g/L) & Quantity & $\mathrm{AU} / \mathrm{ml}$ & $\mathrm{AU} / \mathrm{ml}$ \\
\hline Tryptone (T) & 20 & 6400 & 12800 \\
\hline Yeast extract $(\mathrm{Y})$ & 20 & 800 & 1600 \\
\hline Meat extract $(\mathrm{M})$ & 20 & 3200 & 6400 \\
\hline $\mathrm{T}+\mathrm{Y}$ & $(12,5+7,5)$ & 12800 & 12800 \\
\hline $\mathrm{T}+\mathrm{M}$ & $(12,5+7,5)$ & 12800 & 12800 \\
\hline $\mathrm{Y}+\mathrm{M}$ & $(10+10)$ & 3200 & 3200 \\
\hline $\mathrm{T}+\mathrm{Y}+\mathrm{M}$ & $(10+5+5)$ & 12800 & 12800 \\
\hline Glucose & 20 & 12800 & 12800 \\
\hline Gluconate & 20 & 800 & 800 \\
\hline Fructose & 20 & 1600 & 1600 \\
\hline Mannose & 20 & 12800 & 800 \\
\hline Maltose & 20 & 1600 & 1600 \\
\hline Lactose & 20 & 3200 & 1600 \\
\hline Saccharose & 20 & 1600 & 800 \\
\hline \multirow[t]{4}{*}{ Tween $80(\mathrm{ml} / \mathrm{L})$} & 0 & 400 & 800 \\
\hline & 0,1 & 12800 & 6400 \\
\hline & 0,2 & 12800 & 12800 \\
\hline & 0,5 & 12800 & 12800 \\
\hline \multirow[t]{4}{*}{ Glycerol (g/L) } & 0 & 12800 & 12800 \\
\hline & 1 & 6400 & 800 \\
\hline & 2 & 3200 & 800 \\
\hline & 4 & 800 & 800 \\
\hline
\end{tabular}

\section{Conclusions}

Some strains of LAB isolated from traditional millet-based fermented food (fura) have demonstrated the ability to inhibit the growth of some food-borne pathogens through the production of bacteriocins and therefore could be exploited for their applications in controlling food-borne pathogenic bacteria. Bacteriocins produced by $L b$. reuteri $2-20 \mathrm{~B}$ and $P d$. acidilactici $0-11 \mathrm{~A}$ were partially characterized based on their responses to some physicochemical treatments and were influenced by media composition. Since the effectiveness of bacteriocins are dependent on the chemical and physical properties of foods, they must be fully characterized and tested in appropriate food systems before commercial applications.

\section{Acknowledgements}

This study was supported with financial assistance by the Danish International Development Agency (DANIDA) ENRICA projects and the Government of Ghana (GoG), through the University for Development Studies (UDS)/DANIDA fermented foods project.

\section{References}

Altschul, S. F., Madden, T. L., Schäffer, A. A., Zhang, J., Zhang, Z., Miller, W., \& Lipman, D. J. (1997). Gapped BLAST and PSI-BLAST: a new generation of protein database search programs. Nucleic Acids Res., 25, 3389-3402. http://dx.doi.org/10.1093/nar/25.17.3389

Bonade, J. A., Dagnan, A. J., \& Garver M. J. (2001). production of helveticin from Lactobacillus helveticus. Lett. Applied Mocrobiol., 33, 153-158. http://dx.doi.org/10.1046/j.1472-765x.2001.00969.x

Caplice, E., \& Fitzgerald, G. F. (1999). Food fermentations: role of microorganisms in food production and 
preservation. Int. J. Food Microbiol., 50, 131-149. http://dx.doi.org/10.1016/S0168-1605(99)00082-3

Corsetti, A., Gobbetti, M., \& Smacchi, E. (1996). Antimicrobial activity of sourdough lactic acid bacteria: isolation of a bacteriocin-like inhibitory substance from Lactobacillus sanfrancisco C57. Food Microbiol., 13, 447-456. http://dx.doi.org/10.1006/fmic.1996.0051

Daba, H., Lacroix, C., Huang, J., \& Simard, R. E. (1993). Influence of growth conditions on production and activity of Mesenterocin 52 by strains of Leuconostoc mesenteroides. Appl. Microb. Biotechnol, 39, 166-173. http://dx.doi.org/10.1007/BF00228601

De Vuyst, L., \& Vandamme, E. J. (1994). Antimicrobial potential of lactic acid bacteria. In F. Leroy, \& De L. Vuyst (Eds.), Bacteriocins of Lactic Acid Bacteria: Microbiology, Genetics and Applications (pp. 91-142). London, UK: Blackie Academic and Professional. http://dx.doi.org/10.1007/978-1-4615-2668-1_3

Ennahar, S., Sonomoto, K., \& Ishizaki, A. (1999). Class IIa bacteriocins from lactic acid bacteria: antibacterial $\begin{array}{lllll}\text { activity and food preservation. } J . & \text { Biosci. Bioeng., } & \text { 87, } & \text { 705-716. }\end{array}$ http://dx.doi.org/10.1016/S1389-1723(99)80142-X

Gevers, D., Huys, G., \& Swings, J. (2001). Applicability of rep-PCR fingerprinting for identification of $\begin{array}{lllll}\text { Lactobacillus } & \text { species. }\end{array}$ http://dx.doi.org/10.1111/j.1574-6968.2001.tb10921.x

Gänzle, M. G., Höltzel, A., Walter, J., Jung, G., \& Hammes, W. P. (2000). Characterization of reutericyclin produced by Lactobacillus reuteri LTH2584. Appl. Environ. Microbiol., 66, 4325-4333. http://dx.doi.org/10.1128/AEM.66.10.4325-4333.2000

Hammes, W. P., \& Vogel, R. F. (1995). The genus Lactobacillus. In B. J. B. Wood, \& W. H. Holzapfel (Eds.), The Lactic Acid Bacteria (1st ed) (pp. 19-51). London, UK: Chapman and Hall. http://dx.doi.org/10.1007/978-1-4615-5817-0_3

Holzapfel, W. H., Geisen, R., \& Schillinger, U. (1995). Biological preservation of foods with reference to protective cultures, bacteriocins and food-grade enzymes. Int. J. of Food Microbiol., 24, 343-362. http://dx.doi.org/10.1016/0168-1605(94)00036-6

Larsen, A. G., Vogensen, F. K., \& Josephsen, J. (1993). Antimicrobial activity of lactic acid bacteria isolated from sour doughs: purification and characterization of bavaricin A, a bacteriocin produced by Lactobacillus bavaricus MI401. J. Appl. Bacteriol., 75, 113-122. http://dx.doi.org/10.1111/j.1365-2672.1993.tb02755.x

Leroy, F., \& De Vuyst, L. (2004). Lactic acid bacteria as functional starter cultures for the food fermentation industry. Trends Food Sci. Technol., 15, 67-78. http://dx.doi.org/10.1016/j.tifs.2003.09.004

Lewus, C. B., \& Montville, T. J. (1992). Further characterization of bacteriocins plantaricin BN, bavaricin MN and pediocin A. Food Biotechnol., 56, 153-174. http://dx.doi.org/10.1080/08905439209549829

Mataragas, M., Drosinos, E. H., \& Metaxopoulos, J. (2003). Antagonistic activity of lactic acid bacteria against Listeria monocytogenes in sliced cooked cured pork shoulder stored under vacuum or modified atmosphere at $4 \pm 2^{\circ} \mathrm{C}$. Food Microbiol., 20, 259-265. http://dx.doi.org/10.1016/S0740-0020(02)00099-0

Messens, W., \& De Vuyst, L. (2002). Inhibitory substances produced by Lactobacillus isolated from sourdoughs - A review. Int. J. Food Microbiol., 72, 31-34. http://dx.doi.org/10.1016/S0168-1605(01)00611-0

Mezaini, A., Chihib, N. E., Bouras, A. D., Arroume, N. N., \& Hornez, J. P. (2009). Antibacterial activity of some lactic acid bacteria isolated from an Algerian dairy product. J. Environ. Pub. Health., 95.

Mollendorff, J. W., Todorov, S. D., \& Dicks, L. M. T. (2006). Comparison of bacteriocins produced by lactic-acid bacteria isolated from Boza, a cereal-based fermented beverage from the Balkan Peninsula. Current Microbiol., 53, 209-216. http://dx.doi.org/10.1007/s00284-006-0075-9

Mørtvedt-Abildgaard, C. I., Nissen-Meyer, J., Jelle, B., Grenov, B., Skaugen, M., \& Nes, I. F. (1995). Production and $\mathrm{pH}$ dependent bactericidal activity of lactocin S, a lantibiotic from Lactobacillus sakei L45. Appl. Environ. Microbiol., 61, 175-179.

Nielsen, D. S., Teniola, O. D., Ban-Koffi, L., Owusu, M., Andersson, T. S., \& Holzapfel, W. H. (2007). The microbiology of Ghanaian cocoa fermentations analysed using culture-dependent and culture-independent methods. Int. J. Food Microbiol., 114, 168-186. http://dx.doi.org/10.1016/j.ijfoodmicro.2006.09.010

Olsen, A., Halm, M., \& Jakobsen, M. (1995). The antimicrobial activity of lactic acid bacteria from fermented maize (kenkey) and their interactions during fermentation. J. Appl. Bacteriol., 79, 506-512. 
http://dx.doi.org/10.1111/j.1365-2672.1995.tb03170.x

Olukoya, D. K., Tichazek, P. S., Butsch, A., Vogel, R. F., \& Hammes, W. P. (1993). Characterization of the bacteriocins produced by Lactobacillus pentosus DK 8 isolated from ogi and L. plantarum DK 9 isolated from fufu. Chem. Mikrobiol. Technol. Lebensm., 15, 65-68.

Owusu-Kwarteng, J., Akabanda, F., Nielsen, D. S., Tano-Debrah, K., Glover, R. L. K., \& Jespersen, L. (2012). Identification of lactic acid bacteria isolated during traditional fura processing in Ghana. Food Microbiol., 32, 72-78. http://dx.doi.org/10.1016/j.fm.2012.04.010

Owusu-Kwarteng, J., Tano-Debrah, K., Glover, R. L. K., \& Akabanda, F. (2010). Process characteristics and microbiology of fura processed in northern Ghana. Nature and Science, 8(8), 41-51.

Parente, E., \& Ricciardi, A. (1994). Influence of $\mathrm{pH}$ on the production of enterocin 1146 during batch fermentation. Lett. Appl. Microbiol., 19(1), 12-15. http://dx.doi.org/10.1111/j.1472-765X.1994.tb00891.x

Riley, M. A., \& Wertz, J. E. (2002). Bacteriocins: evolution, ecology, and application. Ann. Rev. Microbiol., 56, 117-13. http://dx.doi.org/10.1146/annurev.micro.56.012302.161024

Sanni, A. I., Onilude, A. A., Ogunbanwo, S. T., \& Smith, S. I. (1999). Antagonistic activity of bacteriocin produced by Lacobacillus species from igo, an indigenous fermented food. J. Basic microbiol., 3, 189-195. http://dx.doi.org/10.1002/(SICI)1521-4028(199906)39:3<189::AID-JOBM189>3.0.CO;2-R

Todorov, S. D., \& Dicks, L. M. T. (2004). Characterization of mesentericin ST99, a bacteriocin produced by Leuconostoc mesenteroides subsp. dextranicum ST99 isolated from boza. Appl. Microbiol. Biotechnol., 31, 323-329.

Todorov, S. D., \& Dicks, L. M. T. (2004). Effect of medium components on bacteriocin production by Lactobacillus pentosus ST151BR, a strain isolated from beer produced by the fermentation of maize, barley and soy flour. World J. Microbiol. Biotechnol., 20, 643-650. http://dx.doi.org/10.1023/B:WIBI.0000043196.09610.de

Todorov, S. D., \& Dicks, L. M. T. (2005). Characterization of bacteriocins produced by lactic acid bacteria isolated from spoiled black olives. J. Basic Microbiol., 45, 312-322. http://dx.doi.org/10.1002/jobm.200410532

Todorov, S. D., \& Dicks, L. M. T. (2006). Screening for bacteriocin-producing lactic acid bacteria from boza, a traditional cereal beverage from Bulgaria. Comparison of the bacteriocins. Process Biochem., 41, 11-19. http://dx.doi.org/10.1016/j.procbio.2005.01.026

Todorov, S. D., Onno, B., Sorokine, O., Chobert, J. M., Ivanova, I., \& Dousset, X. (1999). Detection and characterization of a novel antibacterial substance produced by Lactobacillus plantarum ST 31 isolated from sourdough. Int. J. Food Microbiol., 48, 167-177. http://dx.doi.org/10.1016/S0168-1605(99)00048-3

Van Der Merwe, I. R., Bauer, R., Britz, T. J., \& Dicks, L. M. T. (2004). Characterization of thoeniicin 447, a bacteriocin isolated from Propionibacterium thoenii strain 447. Int. J. of Food Microbiol., 92, 153-160. http://dx.doi.org/10.1016/j.ijfoodmicro.2003.09.004

Aasen, I. M., Møretrø, T., Katla, T., Axelsson, L., \& Storrø, I. (2000). Influence of complex nutrients, temperature and $\mathrm{pH}$ on bacteriocin production by Lactobacillus sakei CCUG 42687. Appl. Microbiol. Biotechnol., 53(2), 159-166. http://dx.doi.org/10.1007/s002530050003 